\title{
Terrestrial Biomass and Carbon Stock in Broad-leaved Forests of Punakha District, Western Bhutan
}

\author{
S. Tshering*† and P. Rinzin** \\ *Department of Environment and Climate Studies, College of Natural Resources, Royal University of Bhutan, \\ Punakha, Bhutan \\ **Department of Sustainable Development, College of Natural Resources, Royal University of Bhutan, Punakha, Bhutan \\ $†$ Corresponding author: S. Tshering; desangma06@gmail.com
}

\author{
Nat. Env. \& Poll. Tech. \\ Website: www.neptjournal.com \\ Received: 16-04-2021 \\ Revised: 27-05-2021 \\ Accepted: 06-06-2021 \\ Key Words: \\ Carbon stock \\ Terrestrial biomass \\ Broad-leaved forest \\ Volumetric equation
}

\begin{abstract}
The present study assessed the terrestrial biomass of broad-leaved forests to determine the carbon storage potential of each tree species in Punakha. The assessment was based on a woody stem having a minimum of $10 \mathrm{~cm}$ diameter at breast height $(\mathrm{DBH})$ and tree height. Biomass was estimated using volumetric equations and carbon stock by multiplying the constant factor 0.5 to biomass. The study covered 41 sampling plots of $31.62 \mathrm{~m} \times 31.62 \mathrm{~m}$ and recorded a total of 24 tree species. Total biomass

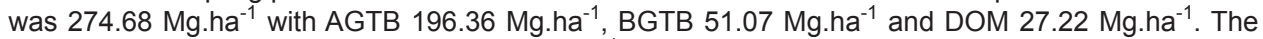

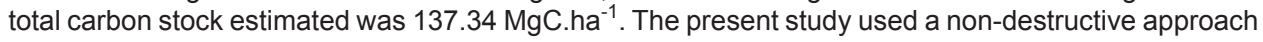
to assess the carbon storage potential of each broad-leaved tree species and concludes that Punakha broad-leaved forest has the potential to accumulate more biomass and carbon stock, as DBH classwise biomass and carbon distribution showed right-skewed trend indicating young forest stands.
\end{abstract}

\section{INTRODUCTION}

Bhutan today has a total forest coverage of 2,730,889 ha which constitutes $71 \%$ of the total geographical area of the country (Amatya et al. 2018, Forest Resources Management Division [FRMD] 2016a). The present study area alone contributes 79,316 ha $(72 \%)$ of forest cover of the total area of 109,878 ha of the Punakha District (FRMD 2016a). The total biomass of Bhutan's forests was estimated to be about 1109 million tonnes and forest carbon stock 709 million tonnes including 188 million tonnes of soil organic carbon (Forest Resources Management Division [FRMD] 2016b). Bhutan's rich forest cover and its high Green House Gas (GHG) sequestration potential were reinforced by a constitutional mandate that a minimum of $60 \%$ of the country's total land be maintained under forest cover for all times (Ministry of Agriculture 2009).

The importance of forests have attracted considerable attention in the recent past especially after the inception of the Kyoto Protocol as it provides ecosystem services as significant terrestrial carbon (C) sink (FRMD 2016b, Rabha 2014, Wellbrock et al. 2017). Forests are one of the vital components in the socio-economic system especially for forest-dependent households (Sahu et al. 2015, Salunkhe et al. 2018). Furthermore, forests have led to estimate global carbon budget and the estimation of carbon (C) stocks to better understand their function in the global carbon cycle as a mitigation measure or a source of carbon in response to climate change (Malhi et al. 1998, Murthy et al. 2015, Nakai et al. 2009).

Aboveground tree biomass (AGTB), belowground tree biomass (BGTB), deadwood, litter, and soil organic matter (SOM) are five carbon pools in the forest ecosystem (FRMD 2016b). Biomass can be measured either in terms of fresh weight or dry weight and it can be both dead and living components. The amount of $\mathrm{C}$ sequestrated by broad-leaved forests can be inferred from total biomass accumulated as approximately $50 \%$ of forest dry biomass is C (Beets et al. 2012, Cairns et al. 2003, Justine et al. 2015, Vashum \& Jayakumar 2012, Wolf et al. 2011). Forest ecosystem which covers about 4.1 billion ha globally store about $80 \%$ of aboveground terrestrial $\mathrm{C}$ and $40 \%$ of belowground $\mathrm{C}$ to mitigate global climate change (Ahmad et al. 2015, Lal 2005, Sahu et al. 2015, Wellbrock et al. 2017).

To understand the carbon storage potential of Punakha broad-leaved forests (PBFr), volumetric equations and specific wood density with variables DBH and tree height were used to calculate biomass accumulation and $\mathrm{C}$ stock following a non-destructive approach. The present study 
found out that PBFr plays a vital role as C sinks. Carbon storage potential in different tree species differ depending upon management practices, disturbances, and age of the trees (Mendoza-Ponce \& Galicia 2010).

\section{MATERIALS AND METHODS}

\section{Study Area}

The study was carried out in Punakha District (Fig. 1) approximately located between latitude $27^{\circ} 39^{\prime} 59.99^{\prime \prime} \mathrm{N}$ and longitude $89^{\circ} 49^{\prime} 59.99^{\prime \prime}$ E with elevation ranging from 1200 to above 4500 meters above sea level. It is bordered by Thimphu, Gasa, and Wangdue Phodrang Districts. Temperature varies approximately from minus $4{ }^{\circ} \mathrm{C}$ to $35^{\circ} \mathrm{C}$. The District consists of 79,316 ha $(72 \%)$ of forest cover of a total area of 109,878 ha (FRMD 2016a). Natural mixed forests of broad-leaved evergreen and coniferous trees covered the study area. Dominant tree species recorded were Quercus lanata, Castanopsis tribuloides and Rhododendron arboretum.

Forests are under threat as a result of increased developmental activities, limiting carbon sequestration capability. Furthermore, only a few studies carried out concentrating on the value of individual broad-leaved tree species' carbon stock potential. In this study, floristic composition and importance level of specific broad-leaved tree species in connection

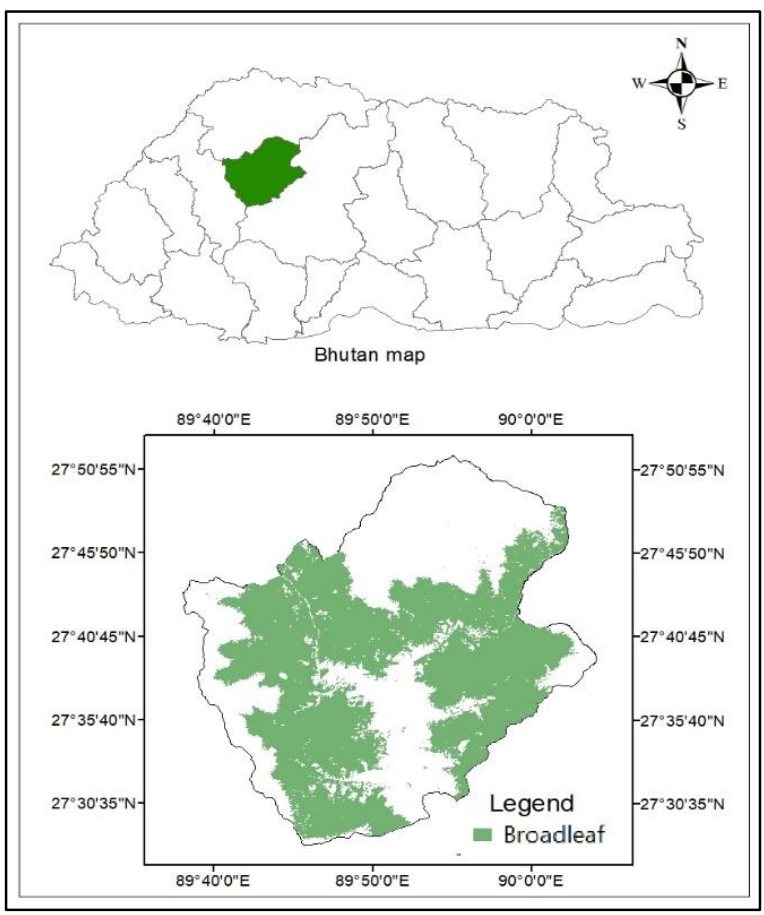

Fig.1: Map of Bhutan showing the study area. to their carbon storage potential were investigated using a total of 41 sampling sites.

\section{Tree Height and DBH Measurement}

The Forest Survey of India (FSI) (2015) and Tshering (2019) methodologies were used to lay a quadrat measuring 31.62 $\mathrm{m} \times 31.62 \mathrm{~m}$ and recorded a total of 24 tree species. For the enumeration, trees were defined as circumferences with a minimum diameter of $10 \mathrm{~cm}$ at breast height $(\mathrm{DBH})$, i.e. $1.37 \mathrm{~m}$ above the ground (Borah et al. 2013, FRMD 2016a, FRMD 2016b, Mani \& Parthasarathy 2009, Rabha 2014, Salunkhe et al. 2016, Shahid \& Joshi 2015). The height and DBH of the trees were measured using a non-destructive approach (Pragasan 2015, Tshering 2019). Clinometer and diameter tape were used to measure the tree height and DBH, respectively. Non-broad-leaved tree species such as conifer species sampled in the same quadrats were excluded as it was not the focus of the current study.

\section{Terrestrial Tree Biomass Estimation}

Non-destructive estimation of biomass was carried out using a volumetric equation (Forest Survey of India [FSI] 1996). The following procedures were considered for the current study. (1) Bole biomass was calculated using the formula $\mathrm{V}$ $\times \mathrm{WD}$ (where, $\mathrm{V}=$ volume of trees $\left[\mathrm{v}: \mathrm{m}^{3}\right.$.tree $\left.{ }^{-1}\right]$, WD=wood specific density $\left[\mathrm{Mg} . \mathrm{m}^{-3}\right]$ ) (Ahmad et al. 2014, Mandal \& Joshi 2015). (2) Aboveground tree biomass (AGTB) was derived by using the formula $\mathrm{BB} \times \mathrm{BEF}$ (where, $\mathrm{BB}=$ bole biomass $\left[\mathrm{Mg} \cdot \mathrm{ha}^{-1}\right], \mathrm{BEF}=$ biomass extension factor 1.59) (Khan et al. 2015, Mandal \& Joshi 2015). (3) Belowground tree biomass $(\mathrm{BGTB}$ ) was calculated by AGB $\times 0.26$ (where, $0.26=$ constant root-shoot ratio) (Joshi et al. 2020, Shahid \& Joshi 2015, Srinivas \& Sundarapandian 2019, Subashree \& Sundarapandian 2017, Mandal \& Joshi 2015, Sahu et al. 2015). (4) The dead woods and leaf litter in the form of dead organic matter $(\mathrm{DOM})$ were calculated, $(\mathrm{AGTB}+\mathrm{BGTB})$ $\times 0.11$ (where $0.11=$ default factor) (Joshi et al. 2020, Sahu et al. 2015). The total biomass ( $\left.\mathrm{Mg} \cdot \mathrm{ha}^{-1}\right)$ was obtained by adding aboveground and belowground tree biomass including dead woods and leaf litter biomass (DOM).

\section{Total Carbon Stock}

Carbon values for each forest carbon pool were summed to estimate total forest carbon stock (Joshi et al. 2020). Total carbon stock $\left(\mathrm{MgC} \mathrm{ha}^{-1}\right)$ of the broad-leaved forests of Punakha District was then converted into tonnes of $\mathrm{CO}_{2}$ equivalent by multiplying with constant conversion factor 0.5 following the methods of Borah et al. (2013), Chauda hury \& Upadhaya (2016), Shahid \& Joshi (2015), Sun et al. (2016), Terakunpisut et al. (2007) and Tshering (2019). 
The following equation was used to calculate the total forest carbon stock:

$$
\mathrm{TC}=\mathrm{C}(\mathrm{AGTB})+\mathrm{C}(\mathrm{BGTB})+\mathrm{C}(\mathrm{DOM})
$$

Where, $\mathrm{TC}=$ Total carbon stock $\left(\mathrm{CMg} \cdot \mathrm{ha}^{-1}\right), \mathrm{C}(\mathrm{AGTB})=$ Carbon stock in aboveground tree biomass, $\mathrm{C}(\mathrm{BGTB})=$ Carbon stock in belowground tree biomass, and $\mathrm{C}(\mathrm{DOM})=$ Carbon stock in dead woods and leaf litter in the form of dead organic matter.

\section{RESULTS AND DISCUSSION}

\section{Biomass and Carbon}

Total biomass and $\mathrm{C}$ stock accumulations were 274.68 Mg.ha ${ }^{-1}$ and $137.33{\mathrm{MgC} . \mathrm{ha}^{-1}}$ respectively (Table 1) and it is within the range of the standing biomass of different forest types of Western Himalaya ranging from $123.89 \pm 26.33$ to $537.77 \pm 56.34 \mathrm{Mg} \cdot$ ha $^{-1}$ (Singh \& Verma 2018). Values reported in the present results were lower than the values of tropical evergreen and deciduous forests of Uttara Kannada District with 344-417 MgC.ha- (Murthy et al. 2015). Further, total biomass ( $54 \pm 19$ million tonnes) and $\mathrm{C}$ stock (25 \pm 9 million tonnes) reported for the whole Punakha District by FRMD (2016b) was much higher than the values reported in the present results. This was owing to the fact that the previous study included total biomass estimates of trees (all forest types), saplings, shrubs, and herbs, as well as soil carbon, but the current study only included biomass and $\mathrm{C}$ estimates of trees (of the broad-leaved forest). However, the $\mathrm{C}$ stock of the study area was found comparable to tropical rain

Table 1: Species-wise tree density (count.ha $\left.{ }^{-1}\right)$, biomass $\left(\mathrm{Mg} \mathrm{ha}^{-1}\right)$, and carbon $\left(\mathrm{MgC}^{-h^{-1}}\right)$.

\begin{tabular}{|c|c|c|c|c|c|c|c|}
\hline \multirow[t]{2}{*}{ Sl. No. } & \multirow[t]{2}{*}{ Species } & \multirow[t]{2}{*}{ Tree density } & \multicolumn{3}{|c|}{ Biomass } & \multirow{2}{*}{$\begin{array}{l}\text { Total } \\
\text { biomass }\end{array}$} & \multirow[t]{2}{*}{ Total carbon } \\
\hline & & & AGTB & BGTB & DOM & & \\
\hline 1 & Quercus lamellosa & 43.44 & 0.2 & 0.05 & 0.03 & 0.28 & 0.14 \\
\hline 2 & Michelia doltsopa & 19.59 & 1.85 & 0.48 & 0.26 & 2.59 & 1.30 \\
\hline 3 & Myrsine semiserrata & 14.48 & 2.11 & 0.55 & 0.29 & 2.95 & 1.48 \\
\hline 4 & Lindera pulcherrima & 15.33 & 1.15 & 0.3 & 0.16 & 1.61 & 0.81 \\
\hline 5 & Quercus Glauca & 27.26 & 8.34 & 2.17 & 1.16 & 11.67 & 5.84 \\
\hline 6 & Quercus oxyodon & 29.81 & 16.33 & 4.25 & 2.26 & 22.84 & 11.42 \\
\hline 7 & Symplocos glomerata & 19.59 & 6.83 & 1.78 & 0.95 & 9.56 & 4.78 \\
\hline 8 & Symplocos ramosissima & 30.66 & 3.91 & 1.02 & 0.54 & 5.47 & 2.74 \\
\hline 9 & Rhododendron arboreum & 115.84 & 6.65 & 1.73 & 0.92 & 9.30 & 4.65 \\
\hline 10 & Quercus semecarpifolia & 11.93 & 6.97 & 1.81 & 0.97 & 9.75 & 4.88 \\
\hline 11 & Lyonia ovalifolia & 102.21 & 0.29 & 0.07 & 0.04 & 0.40 & 0.20 \\
\hline 12 & Castanopsis tribuloides & 118.40 & 76.86 & 19.98 & 10.65 & 107.49 & 53.75 \\
\hline 13 & Quercus griffithii & 58.77 & 10.29 & 2.68 & 1.43 & 14.40 & 7.20 \\
\hline 14 & Quercus lanata & 120.95 & 11.98 & 3.12 & 1.66 & 16.76 & 8.38 \\
\hline 15 & Schima wallichii & 34.07 & 5.16 & 1.34 & 0.71 & 7.21 & 3.61 \\
\hline 16 & Michelia champaca & 12.78 & 8.08 & 2.1 & 1.12 & 11.30 & 5.65 \\
\hline 17 & Daphniphyllum chartaceum & 52.81 & 4.8 & 1.25 & 0.66 & 6.71 & 3.36 \\
\hline 18 & Myrica esculenta & 14.48 & 0.99 & 0.26 & 0.14 & 1.39 & 0.70 \\
\hline 19 & Toona ciliata & 20.44 & 0.06 & 0.02 & 0.01 & 0.09 & 0.05 \\
\hline 20 & Ilex dipyrena & 31.52 & 18.14 & 4.72 & 2.51 & 25.37 & 12.69 \\
\hline 21 & Albizia lebbeck & 28.11 & 5.27 & 1.37 & 0.73 & 7.37 & 3.69 \\
\hline 22 & Eurya acuminata & 15.33 & 0.05 & 0.01 & 0.01 & 0.07 & 0.04 \\
\hline 23 & Cinnaтотит glaunduliferum & 13.63 & 0.04 & 0.01 & 0.01 & 0.06 & 0.03 \\
\hline \multirow[t]{5}{*}{24} & Juglans regia & 48.55 & 0.014 & 0.004 & 0.002 & 0.02 & 0.01 \\
\hline & Poll biomass & - & 196.36 & 51.07 & 27.22 & - & - \\
\hline & Pool carbon & - & 98.18 & 25.54 & 13.61 & - & - \\
\hline & Total & 999.98 & 196.36 & 51.07 & 27.22 & 274.68 & 137.33 \\
\hline & Mean & 41.67 & 8.18 & 2.13 & 1.13 & 11.44 & 5.72 \\
\hline
\end{tabular}


forest (Ton Mai Yak station) (137.73 \pm 48.07 tonne.C.ha $\left.{ }^{-1}\right)$, dry evergreen forest (KP 27 station) $(70.29 \pm 7.38$ tonneC. $\mathrm{ha}^{-1}$ ), and mixed deciduous forest (Pong Phu Ron station) 48.14 \pm 16.72 tonneC. $^{-1} a^{-1}$ of Thong Pha Phum National Forest (Terakunpisut et al. 2007).

The AGTB score of the present study (196.36 Mg.ha' ${ }^{-1}$ ) was found lower than the tropical forest of Nagathol forest (261.64 Mg.ha ${ }^{-1}$ ) and higher than that of Monbel forest (166.94 Mg.ha ${ }^{-1}$ ), Rose Kandy (144.01 Mg.ha ${ }^{-1}$ ), Bhuban hill (116.8 Mg.ha ${ }^{-1}$ ) and Dolu forest (99.10 Mg.ha ${ }^{-1}$ ) (Borah et al. 2013). However, the present AGTB score falls within the biomass range of temperate forests of Kashmir Himar laya (Dar \& Sundarapandian 2015) and tropical dry forest of East Godavari region, Andhra Pradesh (58.04 to 368.39

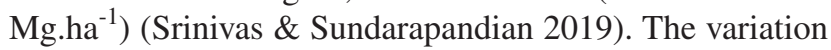
in the distribution of biomass and $\mathrm{C}$ stocks in forest ecosystems could be due to geographical regions and their locality factors (Joshi et al. 2020), forest types, species composition, vegetation management pattern, and stand age (Chaudhury \& Upadhaya 2016, Singh \& Verma 2018).

Biomass accumulation and $\mathrm{C}$ stock potential varied among the tree species of Punakha Broad-leaved Forests
(PBFr). The Castanopsis tribuloides had the highest biomass accumulation and C stock (107.49 Mg.ha ${ }^{-1}$ and $53.75 \mathrm{MgC}$. $\mathrm{ha}^{-1}$ respectively) whereas the lowest value was recorded in Juglans regia (0.02 Mg.ha ${ }^{-1}$ and $0.01 \mathrm{MgC} \mathrm{ha}^{-1}$ respectively) among 24 tree species studied (Table 1). The Castanopsis sp was also reported by FRMD (2016b) as one of the 28 major trees to be an important source of biomass in Bhutan. Punakha broadleaf forest was dominated by Quercus lanata, Castanopsis tribuloides, and Rhododendron arboreum with a tree density of 120.95 count.ha $^{-1}, 118.40$ count.ha $^{-1}$, 115.84 count.ha ${ }^{-1}$ respectively and the least in Quercus semecarpifolia with 11.93 count.ha $^{-1}$ of the total 999.98 count.ha ${ }^{-1}$. The considerable variation in tree density could be due to variation in species richness, DBH size, different anthropogenic activities, and environmental factors affecting plant growth (Chaudhury \& Upadhaya 2016, Rabha 2014, Tshering, 2019).

\section{Biomass and Carbon Estimates by DBH Class}

The distribution of biomass and carbon stock in different DBH classes is shown in Fig. 2. The maximum biomass accumulation and carbon stock were observed in 10-19.9

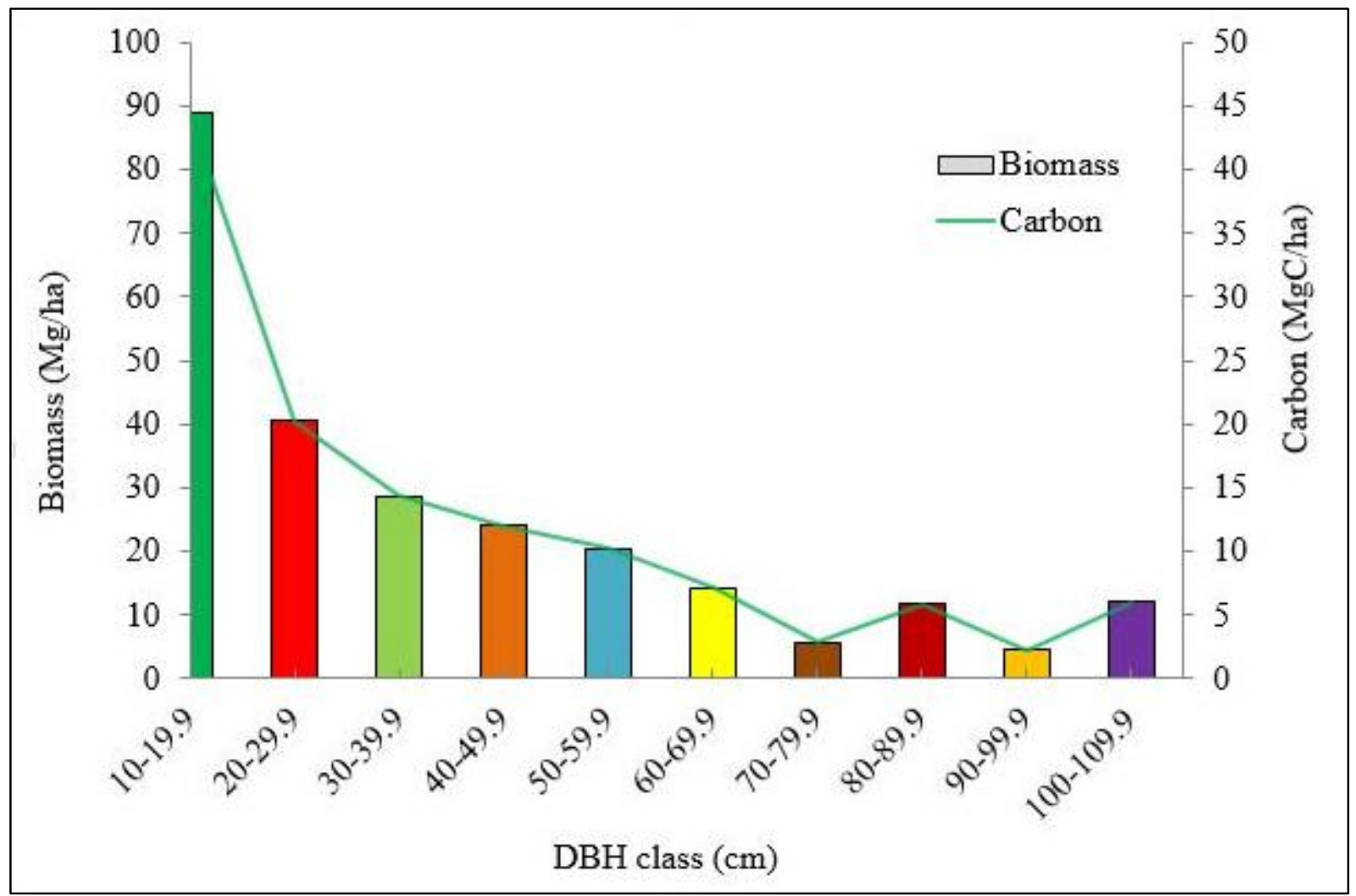

Fig. 2: Biomass and carbon storage in different DBH classes. 
Table 2: Biomass $\left(\mathrm{Mg} \cdot \mathrm{ha}^{-1}\right)$ and carbon stock $\left(\mathrm{MgC}^{-h^{-1}}\right)$ in different tree families.

\begin{tabular}{|c|c|c|c|c|c|c|c|}
\hline Sl.No. & Family & BB & AGTB & BGTB & DOM & TB & $\mathrm{TC}$ \\
\hline 1 & Fagaceae & 77.62 & 123.42 & 32.09 & 17.11 & 172.62 & 86.31 \\
\hline 2 & Magnoliaceae & 5.95 & 9.46 & 2.46 & 11.92 & 23.85 & 11.92 \\
\hline 3 & Myrsinaceae & 1.33 & 2.11 & 0.55 & 0.29 & 2.96 & 1.48 \\
\hline 4 & Lauraceae & 1.98 & 3.15 & 0.82 & 0.44 & 4.40 & 2.20 \\
\hline 5 & Symplocaceae & 5.15 & 8.18 & 2.13 & 1.13 & 11.45 & 5.72 \\
\hline 6 & Ericaceae & 4.36 & 6.94 & 1.80 & 0.96 & 9.70 & 4.85 \\
\hline 7 & Juglandaceae & 2.71 & 4.31 & 1.12 & 0.60 & 6.03 & 3.01 \\
\hline 8 & Theaceae & 2.60 & 4.13 & 1.07 & 0.57 & 5.78 & 2.89 \\
\hline 9 & Daphniphyllaceae & 3.02 & 4.80 & 1.25 & 0.66 & 6.71 & 3.35 \\
\hline 10 & Myricaceae & 0.62 & 0.99 & 0.26 & 0.14 & 1.39 & 0.69 \\
\hline 11 & Meliaceae & 1.99 & 3.16 & 0.82 & 0.44 & 4.43 & 2.21 \\
\hline \multirow[t]{3}{*}{12} & Aquifoliaceae & 11.41 & 18.14 & 4.72 & 2.51 & 25.37 & 12.69 \\
\hline & Total & 118.74 & 188.79 & 49.09 & 36.76 & 274.68 & 137.33 \\
\hline & Mean & 9.90 & 15.73 & 4.09 & 3.06 & 22.89 & 11.44 \\
\hline
\end{tabular}

cm (88.94 Mg.ha ${ }^{-1}$ and $44.47 \mathrm{MgC}^{-h^{-1}}$ respectively) followed by 20-29.9 cm (40.54 Mg.ha ${ }^{-1}$ and 20.27 MgC.ha ${ }^{-1}$ respectively) contrasting the findings of FRMD (2016b), where total aboveground biomass and carbon increased with increasing diameter class peaking at DBH class of 60-70 $\mathrm{cm}$ with $59 \pm 3$ and $28 \pm 2$ million tonnes, though the gradual decrease of biomass accumulation and carbon stock were observed in higher DBH class after picking at mid. How ever, current findings are similar to the dominant size class at $4.5-20 \mathrm{~cm}$ where it potentially provided greater carbon sequestration in the tropical rain forest and dry evergreen forest (Terakunpisut et al. 2007). The least was in 90-99.9 $\mathrm{cm}$ with total biomass $4.49 \mathrm{Mg} \cdot \mathrm{ha}^{-1}$ and carbon $2.24 \mathrm{MgC}$. $\mathrm{ha}^{-1}$, contradicting the findings of Singh and Verma (2018), where individuals lying in DBH class $>150 \mathrm{~cm}$ contributed significantly to carbon stocks.

Variation of different biomass accumulation and carbon stock potential at different DBH classes could be due to the greater number of individuals recorded at lower diameter class $(\geq 10-19.9$ and 20-29.9 $\mathrm{cm} \mathrm{DBH})$ showing a right-skewed trend indicating young forest stands (Fig. 2). Maximum tree count in the DBH class of $10-20 \mathrm{~cm}$ and minimum in 90-100 cm DBH were also reported during the National Forest Inventory of Bhutan by Amatya et al. (2018). Additionally, similar findings were reported by Srinivas and Sundarapandian (2019) in the tropical dry forest of the East Godavari region and by Dar and Sundarapandian (2015) in temperate forests of Kashmir Himalaya.

\section{Tree Family-wise Carbon Stock and Biomass Accumulation}

Fagaceae had a maximum biomass accumulation of 172.62 Mg.ha ${ }^{-1}$ sequestering carbon $86.31 \mathrm{MgC} \cdot \mathrm{ha}^{-1}$ followed by Aquifoliaceae with biomass $25.37 \mathrm{Mg}$.ha ${ }^{-1}$ and carbon 12.69 $\mathrm{MgC} \cdot \mathrm{ha}^{-1}$. The reason for the highest value of biomass and carbon stock in Fagaceae and Aquifoliaceae could be due to higher number of individuals unlike the lowest value estimated in Myricaceae with biomass $1.39 \mathrm{Mg}^{-h^{-1}}$ and carbon 0.69 MgC.ha ${ }^{-1}$. Singh and Verma (2018) found that a larger number of people has a similar effect on biomass and carbon density in diverse forest types in the Western Himalaya. Other reasons for biomass and carbon distribution variation in different tree families could be higher DBH size, age, and environmental factors (Chaudhury \& Upadhaya 2016, Rabha 2014, Tshering 2019, Zhang et al. 2019). Biomass accumulation and carbon sequestration potential variation of different tree families were shown in Table 2.

The Castanopsis tribuloides and Quercus lamellose under family Fagaceae, and Lyonia ovalifolia and Rhododendron arboretum belonging to Ericaceae were found with greater biomass storage and carbon sequestration potential. Species that have high carbon sequestration potential should be planted that might be capable of reducing the carbon emitted due to deforestation and other anthropogenic activities. If the carbon problem is to be managed through forest management, trees with low biomass and carbon sequestration capacity must be eliminated or replaced with other tree species that store more carbon. 


\section{CONCLUSIONS}

The study pertaining to estimation of carbon stock in broadleaved forests of Punakha District covered 41 sampling plots of $31.62 \mathrm{~m} \times 31.62 \mathrm{~m}$ and recorded a total of 24 tree species. Total biomass and carbon stock estimated were 274.68 Mg.ha ${ }^{-1}$ and 137.33 MgC.ha ${ }^{-1}$ respectively. Biomass accumulation and carbon stock distribution in different DBH classes showed a right-skewed trend indicating young forests for huge carbon sequestration potential in the future if it's conserved sustainably. The present study covered only broadleaved forests, so we recommend future researchers to carry out similar studies on conifer tree species.

\section{ACKNOWLEDGEMENT}

We are thankful to the College of Natural Resources (CNR) for providing financial support. We are grateful to Mr. Karma Sherub from the Department of Forest Science in College of Natural Resources and Mr. Chetenla from Thimphu Forest Division under Department of Forests and Park Services for their support during fieldwork and analysis.

\section{REFERENCES}

Ahmad, A., Mirza, S.N. and Nizami, S.M. 2014. Assessment of biomass and carbon stocks in the coniferous forest of Dir Kohistan, Kpk. Pak. J. Agric. Sci., 51(2): 345-350.

Ahmad, A., Nizami, S.M., Marwat, K.B. and Muhammad, J. 2015. Annual accumulation of carbon in the coniferous forest of Dir Kohistan: an inventory-based estimate. Pak. J. Bot. , 47: 115-118.

Amatya, S., Yangden, K., Wangdi, D., Phuntsho, Y. and Dorji, L. 2018. National forest inventory of Bhutan: Shift in role from traditional forestry to diverse contemporary global requirements. Journal of Forest and Livelihood, 17(1): 127-138.

Beets, P.N., Kimberley, M.O., Oliver, G.R., Pearce, S.H., Graham, J.D. and Brandon, A. 2012. Allometric equations for estimating carbon stocks in natural forests in New Zealand. Forests, 3: 818-839.

Borah, N., Nath, A.J. and Das, A. K. 2013. Aboveground biomass and carbon stocks of tree species in tropical forests of Cachar District, Assam, Northeast India. Int. J. Econ. Environ. Stud., 39(2): 97-106.

Chaudhury, G. and Upadhaya, K. 2016. Biomass and carbon stock in subtropical broad-leaved forest ecosystem of Meghalaya, Northeast India. Int. J. Econ. Environ. Stud., 42(2): 125-133.

Cairns, M.A., Olmsted, I., Granados, J. and Argaez, J. 2003. Composition and aboveground tree biomass of a dry semi-evergreen forest on Mexico's Yucatan Peninsula. Forest Ecol. Mang., 186(1): 125-132.

Dar, J. A. and Sundarapandian, S. 2015. Variation of biomass and carbon pools with forest type in temperate forests of Kashmir Himalaya, India. Environ. Monit. Assess., 5(3): 81-96.

Forest Resources Management Division (FRMD) 2016a. National Forest Inventory Report: Stocktaking Nation's Forest Resources Volume I. Thimphu: Department of Forests \& Park Services, Ministry of Agriculture \& Forests, Royal Government of Bhutan.

Forest Resources Management Division (FRMD) 2016b. National Forest Inventory Report: Stocktaking Nation's Forest Resources Volume II. Thimphu: Department of Forests \& Park Services, Ministry of Agriculture \& Forests, Royal Government of Bhutan.

Forest Survey of India (FSI) 1996. Volume Equations for Forests of India,
Nepal, and Bhutan. Forest Survey of India, Ministry of Environment, Forest and Climate Change, Kaulagarh, Dehradun, Uttarakhand, India, pp. 249.

Forest Survey of India (FSI) 2015. India State of Forest Report. Forest Survey of India, Ministry of Environment, Forest and Climate Change, Kaulagarh, Dehradun, Uttarakhand, India.

Joshi, R., Singh, H., Chhetri, R. and Yadav, K. 2020. Assessment of carbon sequestration potential in degraded and non-degraded community forests in the Terai region of Nepal. Journal of Forest and Environmental Science, 36(2):113-121.

Justine, M.F., Wanqin, Y., Wu, F., Tan, B., Khan, M.N. and Zhao, Y. 2015. Biomass stock and carbon sequestration in a chronosequence of pinus massoniana plantations in the upper reaches of the Yangtze River. Forests, 6: 3665-3682.

Khan, A., Ahmad, A., Rahman, Z., Siraj-ud-Din., Qureshi, R. and Muhammad, J. 2015. The assessment of carbon stocks in the oak scrub forest of Sheringal valley Dir Kohistan. Open Journal of Forestry, 5: 510-517.

Lal, R. 2005. Forest soils and carbon sequestration. Forest Ecol. Manag, 220:242-258

Malhi, Y., Nobre, A.D., Grace, J., Kruijt, B., Pereira, M.G.P., Culf, A. and Scott, S. 1998. Carbon dioxide is transferred over a central Amazonian rain forest. J. Geophys. Re., 103: 31,593-31,612.

Mandal, G. and Joshi, S. 2015. Biomass accumulation and carbon sequestration potential of dry deciduous forests. International Journal of Ecology and Development, 30(1).

Mani, S. and Parthasarathy, N. 2009. Tree population and above-ground biomass changes in two disturbed tropical dry evergreen forests of peninsular India. Tropical Ecology, 50(2): 249-258.

Murthy, I.K., Bhat, S., Sathyanarayan, V., Patgar, S., Beerappa, M., Bhat, P.R. and Bhat, D.M., Ravindranath, N.H., Khalid, M.A., Prashant, M., Iyer, S., Bebber, D.M. and Saxena, R. 2015. Biomass and carbon stock dynamics in tropical evergreen and deciduous forests of Uttara Kannada District, Western Ghats, India. Glob. J. Sci. Frontier Res., 15(5): 54-69.

Mendoza-Ponce, M. and Galicia, L. 2010. Above-ground and below-ground biomass and carbon pools in a highland temperate forest landscape in central Mexico. Int. J. Forest. Res., 83(5): 497-506.

Nakai, Y., Hosoi, F. and Omasa, K. 2009. Estimating carbon stocks of coniferous woody canopy trees using airborne lidar and passive optical sensor.

Pragasan, L. A. 2015. Assessment of aboveground biomass stock in the Pachaimalai forest of the Eastern Ghats in India. Applied Ecology and Environmental Research, 13(1): 133-145.

Rabha, D. 2014. Aboveground biomass and carbon stocks of an undisturbed regenerating sal (Shorea robusta gaertn. f.) forest of Goalpara District, Assam, Northeast India. Int. J. Environ., 3(4): 121.

Ministry of Agriculture. 2009. National Forest Policy of Bhutan. Ministry of Agriculture, Thimphu, Bhutan, pp. 16.

Sahu, S.C., Sharma, J. and Ravindranath, N.H. 2015. Carbon stocks and fluxes for forests in Odisha (India). Trop. Ecol., 56(1): 77-85.

Salunkhe, O., Khare, P.K., Kumari, R. and Khan, M.L. 2018. A systematic review on the aboveground biomass and carbon stocks of Indian forest ecosystems. Ecol. Processes.

Salunkhe, O., Khare, P.K., Sahu, T.R. and Singh, S. 2016. Estimation of tree biomass reserves in tropical deciduous forests of central India by non-destructive approach. Trop.Ecol., 57(2): 153-161.

Shahid, M. and Joshi, S.P. 2015. Biomass and carbon stock assessment in moist deciduous forests of Doon Valley, Western Himalaya, India. Taiwania, 60(2): 71-76. https://doi.org/10.6165/tai.2015.60.71.

Singh, S. and Verma, A. K. 2018. Biomass and carbon stocks in different forest types of western Himalaya. Tropical Ecology, 59(4): 647-658.

Srinivas, K. and Sundarapandian, S. 2019. Biomass and carbon stocks of trees in the tropical dry forest of east Godavari region, Andhra Pradesh, India. Geology, Ecology, and Landscapes, 3(2):114-122. 
Subashree, K. and Sundarapandian, S. 2017. Biomass and carbon stock assessment in two savannahs of Western Ghats, India. Taiwania, 62(3):272-282.

Sun, X., Wang, G., Huang, M., Chang, R. and Ran, F. 2016. Forest biomass carbon stocks and variation in Tibet's carbon-dense forests from 2001 to 2050. Scientific Reports, 6(1).

Terakunpisut, J., Gajaseni, N. and Ruankawe, N. 2007. Carbon sequestration potential in aboveground biomass of Thong Pha Phum National Forest, Thailand. Appl. Ecol. Environ. Res., 5(2): 93-102.

Tshering, S. 2019. Importance value index and assessment of carbon stocks in western Bhutan Himalaya (Thimphu). Curr. J. Appl. Sci. Technol., $32(2): 1-8$.
Vashum, K.T. and Jayakumar, S. 2012. Methods to estimate above-ground biomass and carbon stock in natural forests-a review. J. Ecosys. Ecogr., 2(4): 45.

Wellbrock, N., Grüneberg, E., Riedel, T. and Polley, H. 2017. Carbon stocks in tree biomass and soils of German forests. Cent. Eur. For. J., 63: $105-112$.

Wolf, S., Eugster, W., Potvin, C., Turner, B.L. and Buchmann, N. 2011. Carbon sequestration potential of tropical pasture compared with afforestation in Panama. Glob. Change Biol., 17: 2763-2780.

Zhang, X., Zhang, X., Han, H., Shi, Z. and Yang, Z. 2019. Biomass accumulation and carbon sequestration in an age-sequence of Mongolian pine plantations in Horqin sandy land, China. Forests, 10: 96. 